\section{Ronald Thexton}

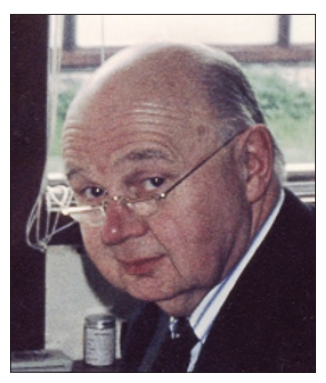

Ronald Thexton died on 6 March 2002, aged 86. Ronald was Consultant Dental and Oral Surgeon to the Princess Margaret Hospital Swindon until his retirement in 1977 in which year he was also honoured by the award of the Queen's Jubilee Medal.

Having qualified from Birmingham in 1937, the following year Ronald joined the Navy and was posted as Surgeon Lieutenant aboard the cruiser HMS Edinburgh in 1939 escorting convoys to Malta and Murmansk in North Russia. In 1940 Ronald married Barbara Stevens with whom he enjoyed many happy years until she died in 1990.

While still a serving officer he qualified as HDDRCS. (Edin) and was appointed Surgeon Lieutenant-Commander in 1944. The following year he was released from Naval service and took up the post of Lecturer in Operative Dental Surgery at Edinburgh University Dental School. In 1950 Ronald was appointed Consultant Dental Surgeon to the Oxford Regional Hospital Board and set up the Department of Oral Surgery at the Princess Margaret Hospital Swindon, then the first new hospital of the fledgling NHS.

In his long consultant career Ronald enjoyed the staunch support of colleagues Norman duPlessis and Bob McGowan and was an enthusiastic participant in many of the developments of the day, including advising on the first UK pilot of a Centralised Sterile Instrument Supply operating theatre system. He was part of the founding organisation of the British Association of Oral Surgeons (now BAOMS) and of the Hospitals Group of the British Dental Association. An astute administrator and manager, Ronald always found a way of achieving his objectives and his
He was part of the founding organisation of the British Association of Oral Surgeons (now BAOMS) and of the Hospitals Group of the British Dental Association. An astute administrator and manager, Ronald always found a way of achieving his objectives.

department and patients benefited greatly from his efforts.

In the 1940's Ronald began painting in oils under the guidance of a Scottish Royal Academician James Cowie RSA and studied at Edinburgh College of Art. Painting became a life-long obsession that he pursued in his retirement. Many friends, colleagues and former patients benefited from the informal teaching sessions he held in his studio. He exhibited at the Royal Academy in 1983, 1988 and 1994 and his paintings were hung and sold in a number of galleries. His works are prized possessions of many of his friends, frequently received as gifts, or purchased at exhibitions he held to support local charities.

Ronald's achievements and expertise extended on to the rugby field and he was also an accomplished musician playing the classical guitar with acclaimed sensitivity. Whilst a student he had also played piano, trumpet and drums in a jazz band.

To his daughter Nicola and son Michael, his many friends and grateful past-patients extend their sympathies. He will be fondly remembered.

John Fieldhouse

\title{
Catherine Taylor Green (née Morton)
}

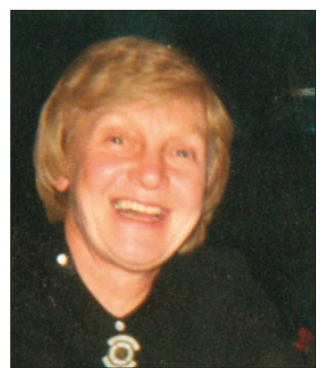

A host of friends and colleagues will be very sad to hear of the death of Catherine in Southport General Hospital on 24 February 2003.

Catherine qualified LDS at St Andrews University in 1942. She worked as a locum in the Perth area during her husband's army service. After his return they moved to Staleybridge and then to Burscough in West Lancashire where they made

She joined the Duke of Edinburgh's Award Scheme at its inception in the 1960 s as a voluntary worker... Her tremendous work in this field was recognised by her being granted the award of Member and later Lady of the Royal Victorian Order by the Queen. their permanent home.

For the next few years she worked part-time for the local authorities of Liverpool and Lancashire (later Sefton) and then started a practice in Burscough.

Catherine had many outside interests; she initially started running a youth club in Ormskirk and sitting on the management committee. She sat on the executive committee on the National Council for Youth Services for 26 years during which time she was first deputy chairperson then vice-president. This involved her participating with the Duke of Edinburgh's Award Scheme which she joined at its inception in the 1960s as a voluntary worker. As the Award Scheme grew, Catherine became the first Northwest Regional Officer. She organised courses in Lancashire, Cheshire and Cumbria. Her tremendoous work in this field was recognised by her being granted the award of Member and later Lady of the Royal Victorian Order by the Queen. She was also Chair of the Ormskirk and West Lancashire Medical Society and later Secretary for several years. Her charitable work and her hospitality made her well known and loved in many circles.

Her family was very important to her. Her husband Michael pre-deceased her. She is survived by three sons and two daughters, grandchildren and great-grandchildren. 